ENTREPRENEURSHIP AND SUSTAINABILITY ISSUES

ISSN 2345-0282 (online) http://jssidoi.org/jesi/

2020 Volume 8 Number 2 (December)

http://doi.org/10.9770/jesi.2020.8.2(61)
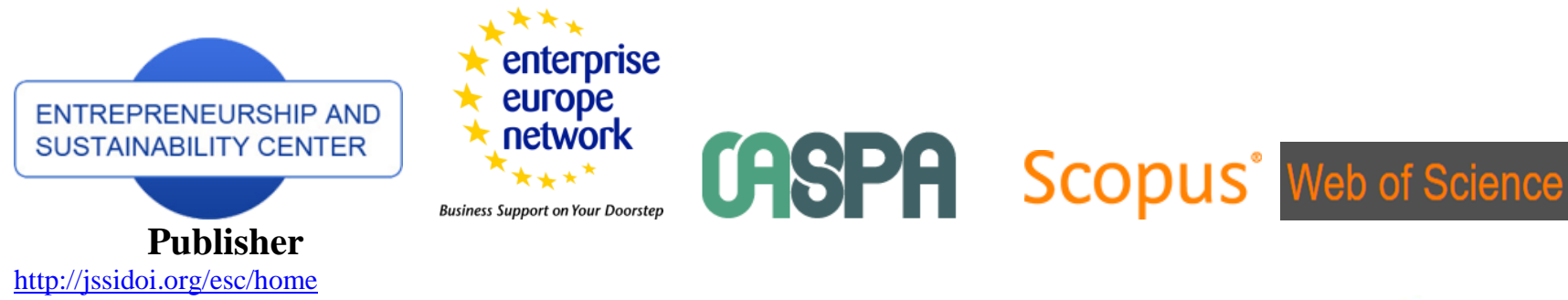

http://jssidoi.org/esc/home

Business Support on Your Doorstep

1) Clarivate

Analytics

\title{
DISCOVERING THE ROLE OF INTELLECTUAL CAPITAL IN LATIN AMERICA: INSIGHTS
} FROM ECUADOR

\author{
Mariuxi Pardo-Cueva ${ }^{1}$, Guillermo Antonio Dávila ${ }^{2}$, Laura Magali Chamba-Rueda ${ }^{3}$ \\ 1,3 Department of Business Sciences, Universidad Técnica Particular de Loja, Loja, Ecuador \\ ${ }^{2}$ Knowledge Engineering Department, Federal University of Santa Catarina, Florianopolis, Brazil \\ E-mails: ${ }^{\text {mcpardo@utpl.edu.ec; }}{ }^{2}$ davila.guillermo@gmail.com; 3 Imchamba@utpl.edu.ec
}

Received 14 February; accepted 30 September 2020; published 30 December 2020

\begin{abstract}
This research aims to characterize the intellectual capital in Ecuadorian companies and to validate the applicability of a scale suitable for this context, considering each of its dimensions (human capital, structural capital, and relational capital), as well as innovation aspects of the Ecuadorian companies. The study uses a mixed approach, including factorial analysis and descriptive statistics, using a sample of 88 companies from different economic sectors, located in a single province of Ecuador. The results verified the applicability of the scale and its usefulness for future studies; and they showed that there are different kinds of configurations of intellectual capital, based on the sector and type of innovation usually implemented by companies. In order to be more innovative, construction firms in Ecuador need to focus more on the structural and relational dimensions of intellectual capital, and accommodation and food services industries should orient their efforts toward further developing their human capital. Future studies may explore the opportunities for enhancing innovation performance based on the management of intellectual capital in more detail, using larger sample sizes.
\end{abstract}

Keywords: intellectual capital; human capital; relational capital; structural capital; Latin America

Reference to this paper should be made as follows: Pardo-Cueva, M., Dávila, G.A., Chamba-Rueda, L.M. 2020. Discovering the role of intellectual capital in Latin America: insights from Ecuador. Entrepreneurship and Sustainability Issues, 8(2), 1006-1026. http://doi.org/10.9770/jesi.2020.8.2(61)

JEL Classifications: O34

\section{Introduction}

Today, knowledge-based organizations are an important part of modern societies (Berezinets, et al. 2016), as companies compete by relying more on their intangible resources as key value factors (Sharabati, Jawad \& Bontis, 2010). These intangible resources, which produce important benefits to overcome the weaknesses of small and medium enterprises (Verbano \& Crema, 2016; Jordão \& Novas, 2017) can be technologies, employee skills, process innovations, organizational structure, creativity, industrial networks, or relationships with customers and external suppliers (Starovic \& Marr, 2004; Keong Choong, 2008). 


\section{ENTREPRENEURSHIP AND SUSTAINABILITY ISSUES}

ISSN 2345-0282 (online) http://jssidoi.org/jesi/

2020 Volume 8 Number 2 (December)

http://doi.org/10.9770/jesi.2020.8.2(61)

Make your research more visible, join the Twitter account of ENTREPRENEURSHIP AND SUSTAINABILITY ISSUES: @Entrepr69728810

Given the characteristics of the market, being technological developments, changes in social conditions, and reduction of the products' life cycles, what will make companies more competitive in the current economic scenario will be the effective management of knowledge assets, including intellectual capital (Zhang \& Lv, 2015; Agostini, et al. 2017).

Intellectual capital (IC) is recognized as one of the most important assets for business results and the basis for market leadership and differentiation, because it provides unique resources that cannot be easily imitated by competitors, and ultimately, it helps to deliver competitive advantage and value for organizations (Lev, 2001; Curado, 2008; Roos, 2017).

Considering the importance of intangible assets for companies, researchers have formulated some methodological frameworks and empirical studies in order to measure and evaluate each one of the components of IC and its economic impact (Goebel, 2015). However, much of this research has focused on assessing and analyzing IC in developed countries, or in knowledge-intensive industries such as technology, pharmaceuticals, banking, and telecommunications.

In emerging countries, empirical studies on innovation-and in the particular case of the role of IC for innovation - are still scarce, and often limited to specific regions and sectors (Jardon \& Martos, 2012), or regional leaders with a large GDP like Brazil (Davila et al., 2019). In response, the present research aims to characterize IC and innovation and to validate the applicability of an instrument in more traditional and less explored industries, located in an emerging country like Ecuador. These sectors are manufacturing, commerce, information and communication technologies, construction, professional activities, housing, and food services.

The research will try to answer the following questions: How is IC and innovation managed in Ecuadorian companies? How can IC be quantified in emerging countries? How can Ecuadorian companies be characterized in relationship to their IC and the type of innovations they make?

Ecuador was chosen for two reasons. Firstly, Ecuador is one of the most economically stable countries with one of the highest GDP per capita in Latin America. According to the World Bank (2019), Ecuador has the 62nd highest GDP in the world, and it has a human development index of 0.762, above average for Latin American countries. Secondly, Ecuador has specific characteristics and at the same time, it has a lack of academic studies when compared with other emerging countries like Mexico or Brazil. Most Ecuadorian firms are SMEs (Superintendencia de Compañías, Valores y Seguros, 2018). Regarding innovation, Ecuador is ranked 99 worldwide according to the Global Innovation Index (GII, 2019), and this shows a need for the development of innovation capabilities. Private firms make huge investments in formal training for workers and this represents a strength that when combined with quality management and knowledge management, may enhance innovation capabilities. Consequently, Ecuador has good potential for academic analysis that will allow conclusions to be drawn, which will serve as inputs for new studies in the region.

This document is structured as follows: in Section 2, a theoretical review related to IC and innovation is provided. Section 3 describes the methodology, extensively developed in the study. Later, in Section 4, the results found in the research and their respective discussion are presented. Finally, Section 5 shows the conclusions. 


\section{ENTREPRENEURSHIP AND SUSTAINABILITY ISSUES}

ISSN 2345-0282 (online) http://jssidoi.org/jesi/

2020 Volume 8 Number 2 (December)

http://doi.org/10.9770/jesi.2020.8.2(61)

Make your research more visible, join the Twitter account of ENTREPRENEURSHIP AND SUSTAINABILITY ISSUES: @Entrepr69728810

\section{Literature review}

\subsection{Innovation in emerging countries}

In the current context, characterized by globalization and dynamism resulting from technological disruptions and political and economic turbulence, innovation becomes an intrinsic characteristic for companies wishing to survive in the market (Teece, 2010). Innovation is defined by Schumpeter (1927) as the superior condition achieved due to the improvement or development of a new product or production method, or due to the opening of a new market. The interest of managers and academics in innovation is to try to understand how the innovation phenomenon has been growing in recent decades (Baregheh et al. 2009). Baregheh et al. (2009) state that innovation is being analyzed from different disciplines such as management, economics, technology, and engineering. In management, specifically in studies related to knowledge management, innovation has been conceptualized as a product of factors; one of which is the IC of organizations (Edvinsson, Sullivan, 1996; Sullivan, 1998; Bontis \& Fitz-Enz, 2002; Subramaniam \& Youndt, 2005).

Despite the growing interest in the subject, the number of studies has evolved very unevenly when developed and emerging countries are compared. In developed countries, there are empirical studies that have characterized IC, have developed measurement techniques for that variable, and have analyzed the relationship between IC and innovation (Bontis, 2001; Cabrita \& Bontis, 2008; Marques et al. 2006; Maurer et al. 2011; Cabello-Medina et al. 2011; Dumay \& Garanina, 2013; Kianto et al. 2017). Looking at studies on IC and innovation in emerging countries, it is evident that those are scarce and limited in scope to some sectors and regions, and therefore there are greater gaps in knowledge (Jardon \& Martos, 2012). This lack of studies about the influence of IC on the innovative performance of companies in emerging countries is critical. This is due to the pressure on companies to innovate in a context where customer's demands are often more complex, and companies frequently face global competitors with better institutional support, access to technology, qualified personnel, and other resources (Dávila et al. 2019).

In the following section, IC and its dimensions will be discussed, as well as the theoretical relationship between IC and innovation. Subsequently, this construction will be characterized in the Ecuadorian context, and based on the results, proposals will be developed that will serve for future empirical studies on the relationship between IC and innovative performance.

\subsection{Intellectual capital}

The academic literature has provided several definitions related to IC. One of the most influential was established by the authors Stewart \& Losee (1994) who considered IC as "the knowledge a company has in order to create a competitive advantage". It also constitutes the knowledge that is generated within the organization and that can be converted into tangible benefits (Edvinsson \& Sullivan, 1996; Sullivan, 2000).

For Lev (2001), IC is also an intangible source of value, transmitted by innovations in specific projects or human resource management practices of an organization. Marr, Schiuma, \& Neely (2004) further consider that IC is represented by the combination of resources and intangible activities that allows an organization to obtain a competitive advantage through the transformation of material, and financial and human resources into a system capable of creating stakeholder value and organizational innovation.

Jordão \& Novas (2017) consider that IC is composed of the relationship between the material and immaterial resources in the possession of an organization. The same interpretation is made by Kujansivu \& Lönnqvist (2007), 


\section{ENTREPRENEURSHIP AND SUSTAINABILITY ISSUES}

ISSN 2345-0282 (online) http://jssidoi.org/jesi/

2020 Volume 8 Number 2 (December)

http://doi.org/10.9770/jesi.2020.8.2(61)

Make your research more visible, join the Twitter account of ENTREPRENEURSHIP AND SUSTAINABILITY ISSUES: @Entrepr69728810

who mention that IC is made up of all the intangible and non-physical goods that are important in a knowledgeintensive industry.

For Stewart (1997) and Bontis (2001), IC is intellectual material, represented in knowledge, experience, intellectual property, and information that can be used to create wealth; however, Dumay (2016) makes a clarification to this definition considering that it does not take into account the totality of the nature of IC to create wealth, affirming furthermore that the basis of the value creation process (monetary, social, and sustainable) is key to deduct the value and characterization of the IC. Dženopoljac, et al. (2016) further consider that the potential of IC in corporate performance will be evident in terms of the management of this intangible resource.

Current researchers of IC such as Bontis et al. (2015), Dumay \& Garanina (2013), and Kianto, et al. (2010) recognize this intangible asset as a term under construction and with multiple facets, since IC constitutes a multidimensional concept of knowledge assets, experience, and practical capabilities to create value of products and services Dumay (2016), using the intelligence rather than just the financial aspect (Allameh, 2018).

At the same time, it is important to highlight that due to the lack of direction related to the classification of intangible assets, there are several arguments related to this issue which have resulted in IC being categorized between two to four dimensions (Dženopoljac et al., 2016). However, to address this weakness, Bontis (1998); Roos, et al. (1997); Sullivan (2000); Roos (2017), Matricano (2016), Wee \& Chua (2016); and BuenecheaElberdin (2017) identified three main components to categorize IC: human capital, structural capital, and relational capital.

Human capital constitutes the combined knowledge, skill, and innovation capacity that employees have in order to accomplish a task (Edvinsson \& Malone, 1997). It also contains a series of characteristics such as education, knowledge, cultural value, and corporate identity that can influence creativity and the willingness to create new ideas within the company (McGregor, et al. 2004; Martín-de-Castro, et al. 2011). This gives satisfaction to the employee and the improvement of personal and organizational performance (Martínez-Torres, 2006).

Sayyed (2018) determines that human capital is one of the largest and most important dimensions of IC in an organization. Bontis (1998) also points out that human capital constitutes a source of innovation and a strategic element for an organization. FitzPatrick, et al. (2013) agrees with this argument, and, further considers that human capital is one of the key resources of strategic renewal and therefore cannot be replaced by machines; since human capital is "the intelligence of the member of the organization" (Bontis, 1998, 65).

Structural capital constitutes the knowledge incorporated in the structures and processes of the organization, and it includes databases, patents, trademarks, research and development, technology, information systems, strategies, organizational charts, manuals and programs, and all the capabilities of the organization that support employee productivity (Edvinsson \& Malone 1997; Bontis, 2001; Petty \& Cuganesan, 2005 and Nazari \& Herremans, 2007). Casas Nova, et al. (2017) also pointed out that the procedures, rules, systems, and routines are elements that together define the organizational system (structure and processes). Through structural capital, the company can turn the innovation and energy of its human resources into the property of the organization (Seleim, et al. 2004; Casas Novas et al. 2017). Furthermore, it is considered internal capital since the accumulated knowledge within the company's structures, processes, and capacities remain in the company when the employee goes home (FitzPatrick, et al., 2013).

Relational capital constitutes a network of relations between people and groups of people, through which information and knowledge is transferred in a shared way (Roberts, 2003). Relational capital symbolizes the best 


\section{ENTREPRENEURSHIP AND SUSTAINABILITY ISSUES}

ISSN 2345-0282 (online) http://jssidoi.org/jesi/

2020 Volume 8 Number 2 (December)

http://doi.org/10.9770/jesi.2020.8.2(61)

Make your research more visible, join the Twitter account of ENTREPRENEURSHIP AND SUSTAINABILITY ISSUES: @Entrepr69728810

attitude of an organization to incorporate the knowledge that comes from the interaction with the external community, such as suppliers, customers, government, and industry and that it develops throughout its existence (Bontis, 1998; Inkinen, 2015). It is embedded in marketing channels, brand names, reputation, customer satisfaction, franchisees, suppliers, and partners (Bontis, et al. 2000; Davey et al. 2009). Casas Novas et al. (2017) also emphasizes that this capital is not owned by the organization, but it can establish corrective measures with a view to its development and determine connectivity between the elements (internal and external) essential for its formation.

Despite fundamental differences in each of the components of IC, they are not always found separately in organizations. Individual knowledge, for example, is related to human capital, and is often codified and institutionalized through structural capital, which is transferred and used in social networks by social capital. Therefore, the different dimensions of IC influence organizational outcomes, including innovation (Machado et al. 2017).

\subsection{Intellectual capital and innovation}

Innovation is defined as the openness and willingness to create and test new ideas given by a cultural aspect of the company to seek new ways of doing things, being creative in their methods of operation and product introduction (Schumpeter, 1927; Calantone et al. 2002). Several empirical studies (Fernández, et al. 2000; Subramaniam \& Youndt; 2005) concluded that intangible factors have a significant influence on innovation outcomes. For that reason, organizations have realized that they can achieve sustainable innovation through IC and that their success depends largely on their ability to manage this valuable intangible asset (Tootifar, et al. 2014; BuenecheaElberdin, 2017), since knowledge assets, including IC, are essential to maintaining an appropriate innovation environment and developing sustainable innovative capabilities in a competitive environment (Allameh, 2018). Therefore, IC is seen as an antecedent for innovation (Chahal \& Bakshi, 2015).

Some empirical studies have explored the role of IC and its dimensions (relational, structural, and human capital) for enhancing innovation performance. Most studies suggest that relational capital has a positive influence on innovation performance (Capello \& Faggian, 2005; Zerenler, et al. 2008; Dorrego, et al. 2013; of Cabrilo \& Dahms, 2018). The study by Dorrego et al. (2013) using data from SMEs from different industries shows that relational capital is an antecedent of product innovations. More evidence about the positive influence of relational capital on innovation performance was shown in the study by Zerenler, et al. (2008) in a Turkish automotive parts firm, and in studies using data from medium and large-sized manufacturing and service firms from Serbia (Cabrilo \& Dahms, 2018) and Italy (Capello \& Faggian, 2005). In addition, Capello \& Faggian (2005) evidenced that in firms from high technology sectors, the contributions of relational capital to innovation are higher. In SMEs, the situation is not different: using data from high tech Italian manufacturing firms, the study of Agostini, et al. (2017) shows that firms with more relational capital tend to have better firm outcomes.

Regarding structural capital, its importance for leveraging innovation performance was highlighted by several studies around the world (Cabrilo \& Dahms, 2018). Using data from Turkish manufacturing firms, Bayraktaroglu, et. al (2019) demonstrated that structural capital is positively related to innovation performance. Similar results were obtained by Agostini \& Nosella (2017) using data from Italian manufacturing SMEs. The study of Buenechea-Elberdin, et al. (2018) classified 180 medium and large-sized firms into two groups: high tech and low tech firms. Their results evidenced that in high tech firms, structural capital influences innovation performance, with capital renewal as a moderating factor. In low tech firms, Buenechea-Elberdin, et al. (2018) show that structural capital has a direct and positive effect on innovation performance. 


\section{ENTREPRENEURSHIP AND SUSTAINABILITY ISSUES}

ISSN 2345-0282 (online) http://jssidoi.org/jesi/

2020 Volume 8 Number 2 (December)

http://doi.org/10.9770/jesi.2020.8.2(61)

Make your research more visible, join the Twitter account of ENTREPRENEURSHIP AND SUSTAINABILITY ISSUES: @Entrepr69728810

Human capital is highlighted by academics as a critical dimension of IC. Some studies show a direct relationship between human capital and innovation performance (Bayraktaroglu, et al. 2019), and some others posit that this relationship is moderated for organizational capabilities, for instance absorptive capacity (Engelman et al., 2017). The study by Engelman et al. (2019) uses data from Brazilian manufacturing firms and highlights the positive influence of human capital on absorptive capacity, and of absorptive capacity on innovation performance. Similar results were obtained in the study by $\mathrm{Xu} \& \mathrm{Li}$ (2019), which analyzes high tech and low tech manufacturing SMEs from China, and provides evidence that the impact of human capital in high-tech SMEs is greater than that in non-high-tech SMEs. Despite few studies (Cabrilo \& Dahms, 2018) providing evidence of a significant influence of human capital on innovation performance, there seems to be a consensus in academia about the significance of this relationship.

\section{Methodology}

For this paper's purpose, a mixed approach was used. First, a survey was applied in order to collect information about levels of IC and innovation in firms from Loja, Ecuador. In the second step, the scale used for measuring IC was statistically assessed. In the final step, the study presents a descriptive analysis for explaining relevant aspects related to the dimensions of IC and innovation.

\subsection{Sample}

The selected sample was of 88 companies from the city of Loja, from the main economic sectors of the Province of Loja - according to the results of the National Economic Census (INEC, 2011) - such as manufacturing, commerce, information and communication, construction, professional activities, lodging, and food services, as described in Table 1. Companies with active status, and registered with the "Superintendencia de Compañias Valores y Seguros of Ecuador" were considered as the basis for the study. The obtained sample represents $21 \%$ of the total of 424 companies from these sectors in Loja Province. The information was collected through face-toface surveys with managers of tactical or strategic levels of the target companies, between March and August 2018.

Table 1. Distribution of companies in this study.

\begin{tabular}{|l|c|c|}
\hline \multicolumn{1}{|c|}{ Economic Section } & Amount & Percentage \\
\hline Information and communication & 17 & $13.79 \%$ \\
\hline Manufacturing & 27 & $31.03 \%$ \\
\hline Trade & 2 & $2.30 \%$ \\
\hline Construction & 20 & $22.99 \%$ \\
\hline Professional activities & 10 & $11.49 \%$ \\
\hline Accommodation and services & 11 & $12.64 \%$ \\
\hline Total & $\mathbf{8 7}$ & $\mathbf{1 0 0 \%}$ \\
\hline
\end{tabular}

Source: Results of the study

The survey contained 40 questions distributed in five blocks. The first block collected general information of the population (to know, among other things, the sector, size, whether the company is family owned or not, and the percentage of women in it); in the second block, data related to human capital was collected; the third block contained questions focused on structural capital; the fourth block was to collect information related with 


\section{ENTREPRENEURSHIP AND SUSTAINABILITY ISSUES}

ISSN 2345-0282 (online) http://jssidoi.org/jesi/

2020 Volume 8 Number 2 (December)

http://doi.org/10.9770/jesi.2020.8.2(61)

Make your research more visible, join the Twitter account of ENTREPRENEURSHIP AND SUSTAINABILITY ISSUES: @Entrepr69728810

relational capital; and finally, in the fifth block, data related to innovation was collected.The first and fifth blocks of the survey were developed on the basis of open and closed questions; while, from the second to the fourth block, the design was elaborated with a Likert scale, using a scale of 5 options: (1) strongly disagree, (2) disagree, (3) neither agree nor disagree, (4) agree, and (5) strongly agree.

The scale for IC was developed based on several relevant studies from around the world. The human capital dimension was measured using 11 items based on Ganesan et al. (1996), Babin \& Boles (1996), Bontis (2013), Edvinsson \& Malone (1997), Sharabati et al. (2010), Hartline \& Ferrell (1996), Youndt et al. (2004), and Carmeli, 2004 among others. For measuring the structural capital dimension, 10 items from IRSE (2007), Berry (1991), Ulrich et al. (1999), Song and Parry (1993), Tippins \& Sohi (2003), and Youndt et al. (2004) among others were used. Finally, for measuring relational capital, eight items based on Chen et al. (2004), Gallego \& Rodríguez (2005), Warn (2005), Youndt et al. (2004), Bontis (1998), Peña (2002), Bueno et al. (2004), and Yli-Renko et al. (2001) among others were used. The authors that support each item of the IC scale are detailed in the appendix.

The instrument was selected as it was considered appropriate for the Ecuadorian context, after conceptual and applicability validations with two academic specialists from the authors' institution, and two external academics. According to Creswell, \& Creswell (2017), some questions were added and others were modified to guarantee applicability to the Ecuadorian context. Finally, the new IC instrument was validated by a group of five Ecuadorian entrepreneurs to ensure its functionality before data collection. This instrument is shown in Table 2. Finally, based on Calantone, Cavusgil, \& Zhao (2002); and Weerawardena (2003), each company was consulted about its predominant type of innovation: product or process.

\subsection{Analysis Method}

In line with the objective of the present work, which was to characterize the IC and innovation in the companies of Loja, this work had two parts. First, statistical validations of the reliability and validity of the used scale were made to verify if it was applicable and could correctly represent the variables of IC in the Ecuadorian context. Next, the collected data went through a descriptive analysis, following suggestions from Creswell, \& Creswell, (2017). The results were presented and discussed with Ecuadorian and international specialists regarding IC and innovation.

\section{Results analysis and discussion}

After data collection, the suitability of the instrument to measure the components of IC and innovation in the Ecuadorian context was verified (Chart 2). The reliability of each category was confirmed by verifying values greater than 0.6 for indicator loadings (Hair et. al 2010) and values higher than 0.7 (threshold suggested by Nunnally \& Bernstein, 1994) for each construct, following the tests of Dijkstra-Henseler, Jöreskog, and Cronbach's alpha. Convergent validity was confirmed by verifying that the average variance extracted from each construct (AVE) was above 0.5, following the suggestions of Fornell \& Larcker (1981). Then, divergent validity was confirmed by verifying that the cross-loadings and the HTMT coefficient (Heterotrait-Monotrait Ratio) were lower than 0.9 for each category, as suggested by Fornell \& Larcker (1981). Finally, it was verified that all the indicators or questions had a VIF (variance inflation factor) index lower than 3.3 to guarantee the absence of multicollinearity. After the first assessment of the above-mentioned indicators (first iteration), indicator H1 (VIF > 3.3) was eliminated to avoid multicollinearity; indicators H11, E10, and R5 (loadings less than 0.6) to guarantee reliability; and indicators $\mathrm{H} 8, \mathrm{H} 9, \mathrm{E} 3, \mathrm{E} 4, \mathrm{R} 3$, and $\mathrm{R} 4$ (for cross loadings) to guarantee discriminant validity (see details in the Appendix). The second interaction yielded values showing correct reliability and validity, as can be seen in Table 2. 
ENTREPRENEURSHIP AND SUSTAINABILITY ISSUES

ISSN 2345-0282 (online) http://jssidoi.org/jesi/

2020 Volume 8 Number 2 (December)

http://doi.org/10.9770/jesi.2020.8.2(61)

Make your research more visible, join the Twitter account of ENTREPRENEURSHIP AND SUSTAINABILITY ISSUES: @Entrepr69728810

Table 2. Instrument to measure IC in companies in Ecuador.

\begin{tabular}{|c|c|c|c|c|c|}
\hline INDICATORS & Loadings & $\begin{array}{c}\text { Dijkstra- } \\
\text { Henseler's rho } \\
(\rho A)\end{array}$ & 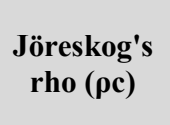 & $\begin{array}{l}\text { Cronbach's } \\
\operatorname{alpha}(\alpha)\end{array}$ & AVE \\
\hline HUMAN CAPITAL (HC) & & 0.898 & 0.918 & 0.896 & 0.617 \\
\hline H1. Employee commitment & & & & & \\
\hline H2. Tasks within deadlines & 0.833 & & & & \\
\hline $\begin{array}{l}\text { H3. Recognition of efforts and } \\
\text { improvements }\end{array}$ & 0.757 & & & & \\
\hline H4. Positive attitude to change & 0.792 & & & & \\
\hline H5. Continuing education & 0.745 & & & & \\
\hline H6. Degree of initiative for improvement & 0.816 & & & & \\
\hline $\begin{array}{l}\text { H7. Satisfaction towards subordinates } \\
\text { H8. Adaption to changes } \\
\text { H9. Competition for the pesition- } \\
\text { H10. Development of creativity } \\
\text { H11. Staff rotation }\end{array}$ & 0.771 & & & & \\
\hline STRUCTURAL CAPITAL (SC) & & 0.896 & 0.903 & 0.879 & 0.539 \\
\hline $\begin{array}{l}\text { E1. Periodic review of the strategic plan } \\
\text { E2. Coordination of departments } \\
\text { E3. Knowledge of activities at all levels- } \\
\text { E4. Incentive to create something new- } \\
\text { E5. Working environment } \\
\text { E6. Description of procedures } \\
\text { E7. Database } \\
\text { E8. Information storage and processing } \\
\text { E9. Computer systems } \\
\text { E10. Use of patents and/or licenses- }\end{array}$ & $\begin{array}{l}0.725 \\
0.774 \\
0.774 \\
0.737 \\
0.614\end{array}$ & & & & \\
\hline RELATIONAL CAPITAL (RC) & & 0.866 & 0.887 & 0.847 & 0.569 \\
\hline $\begin{array}{l}\text { R1. Customer retainment } \\
\text { R2. Relationship with customers } \\
\text { R3. Relationship with suppliers } \\
\text { R4. Assessment of competitors } \\
\text { R5. Cooperation agreements with the } \\
\text { sector }\end{array}$ & $\begin{array}{l}0.763 \\
0.815\end{array}$ & & & & \\
\hline $\begin{array}{l}\text { R6. Relationship with universities, } \\
\text { institutes, or innovation centers }\end{array}$ & 0.704 & & & & \\
\hline R7. Knowledge of community needs & 0.739 & & & & \\
\hline R8. Socially responsible company & 0.853 & & & & \\
\hline
\end{tabular}

Source: Results of the study.

After ensuring that the scale adequately measured IC and its dimensions, the existence of a high correlation between them can be observed, according to the numbers shown in Table 3. This result is similar to previous studies (Bozbura, 2004) and may show that companies develop their IC as a result of generic actions aimed 
Make your research more visible, join the Twitter account of ENTREPRENEURSHIP AND SUSTAINABILITY ISSUES: @Entrepr69728810

toward improving their competencies, rather than as a result of a strategy focused on a certain dimension or set of dimensions of IC.

Table 3 - Correlation between the dimensions of IC in companies in Loja

\begin{tabular}{|ll|c|c|c|}
\cline { 3 - 5 } \multicolumn{1}{c|}{} & $\mathbf{1}$ & $\mathbf{2}$ & $\mathbf{3}$ \\
\hline $\mathbf{1}$ & Human capital & 1 & & \\
\cline { 2 - 5 } $\mathbf{2}$ & Structural capital & 0.6271 & 1 & \\
\cline { 2 - 5 } $\mathbf{3}$ & Relational capital & 0.7209 & 0.7355 & 1 \\
\cline { 3 - 5 } & & &
\end{tabular}

Source: Results of the study.

After verifying the scale, IC characteristics and innovation of the studied companies were analyzed using descriptive analysis.

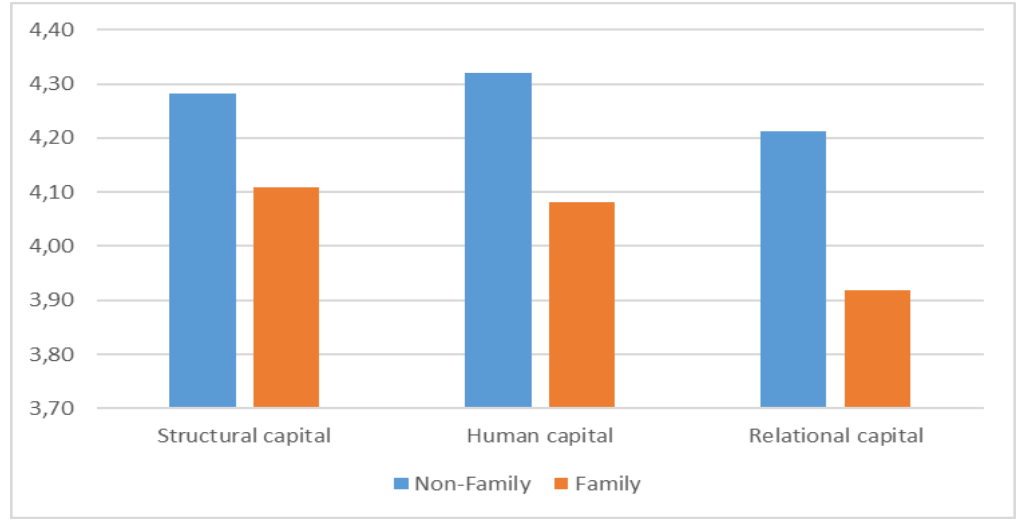

Fig 1. Average IC by type of business

Source: Results of the study

Figure 1 identifies, on average, greater efficiency of the three components of IC (human, structural, and relational) in companies where family ties are not predominant. These results are due to the fact that in family businesses there are greater restrictions or a tendency to increase the dispersion of ownership and even more of their intangible assets. At the same time, a lower average (3.92) was observed in family businesses for relational capital, as most family businesses avoid maintaining entries of external people for fear that they may take control of the organization (Goyzueta, 2013). However, Rodríguez-Suárez, et al. (2013) emphasize the external relations that family businesses must maintain, because of their decision-making processes and, above all, because they are dynamic companies. 
Make your research more visible, join the Twitter account of ENTREPRENEURSHIP AND SUSTAINABILITY ISSUES: @Entrepr69728810

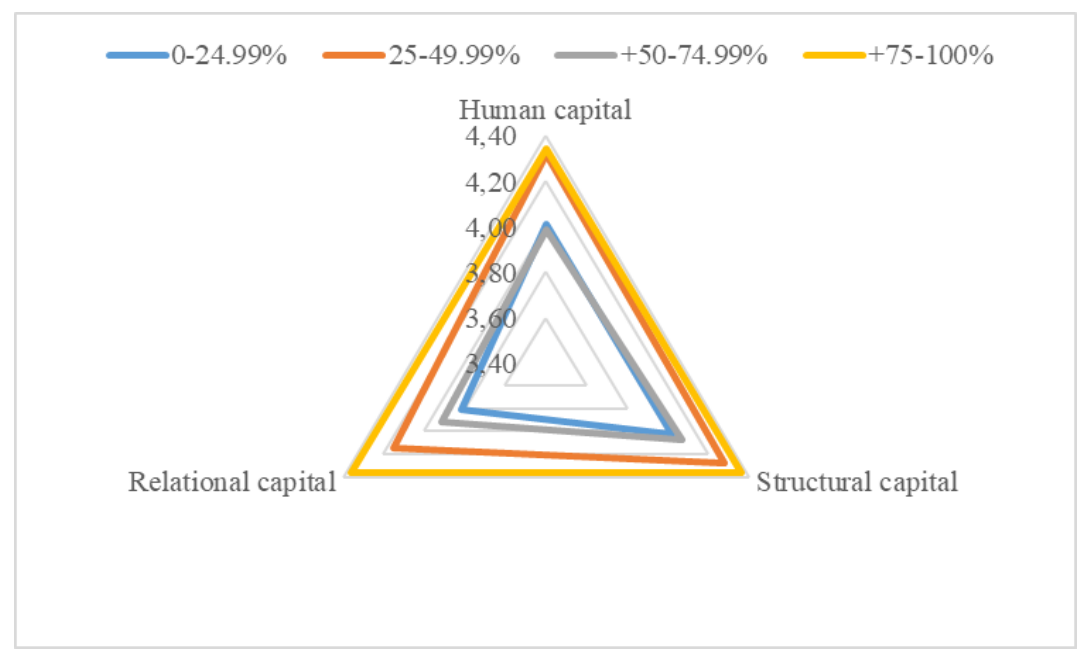

Fig 2. Average of IC components according to \% of women in each company. Source: Results of the study.

In Figure 2, the contribution of the female gender in determining intellectual capital is shown, denoting that when there is greater involvement of women (between $75 \%$ and $100 \%$ and between $25 \%$ and $50 \%$ ), the structure of IC in each of its components (human, structural, and relational) has a greater contribution to the results of the organization. It is considered that women have the ability to create a favorable environment for companies (Granelli \& Robotti, 2016). On the other hand, studies such as that of López (2013) consider that in organizations there should be an equal presence of men and women, constituting a source of creativity and inclusion for entities. Other research supports this statement by ensuring that to assess the IC and management of organizations, the distinction between men and women does not matter because the most relevant factors are the competencies of workers and not their gender (Trequattrini, et al, 2018).

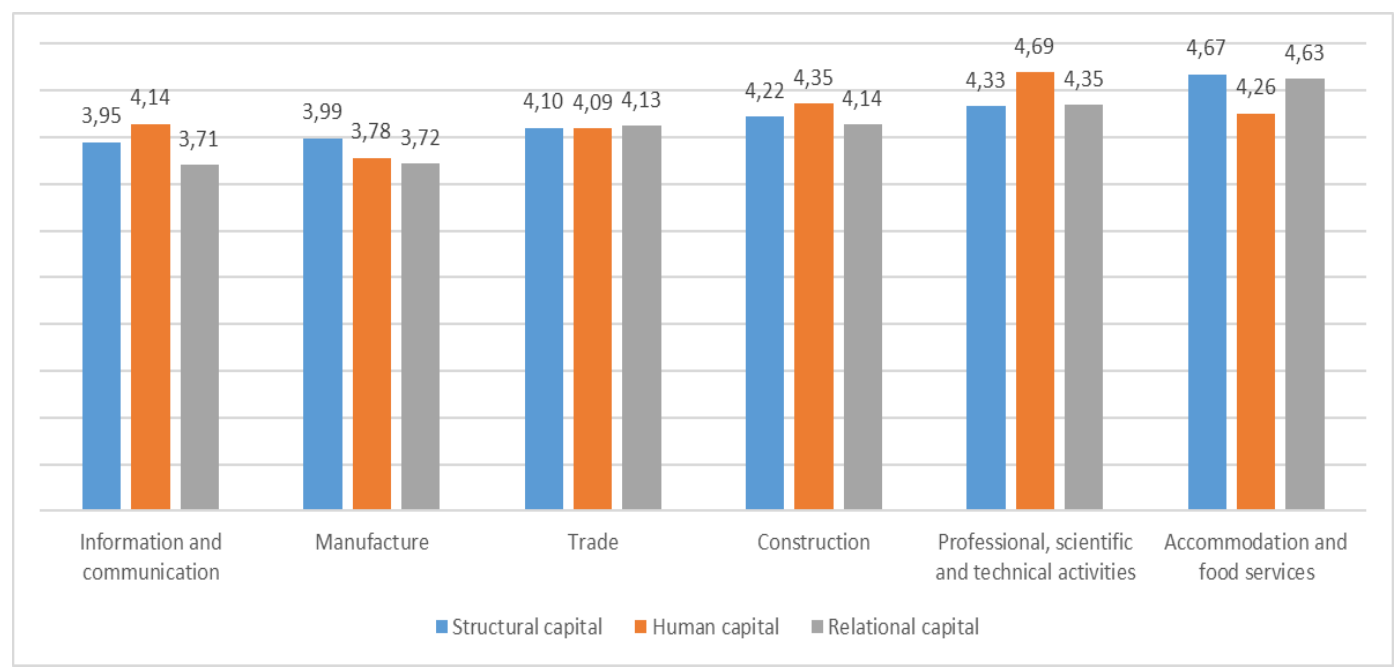

FFig 3. Average IC by economic sector Source: Results of the study. 


\section{ENTREPRENEURSHIP AND SUSTAINABILITY ISSUES}

ISSN 2345-0282 (online) http://jssidoi.org/jesi/

2020 Volume 8 Number 2 (December)

http://doi.org/10.9770/jesi.2020.8.2(61)

Make your research more visible, join the Twitter account of ENTREPRENEURSHIP AND SUSTAINABILITY ISSUES: @Entrepr69728810

Figure 3 shows the distribution of the components of IC by each economic sector of study. It can be seen that in the service sectors, especially knowledge-intensive ones - those related to professional, scientific, and technical activities - there is greater efficiency of human capital. For instance, previous studies in Tunisian ICT firms showed that incremental innovations are positively linked to human capital (Berraies, 2019). Other studies highlighted the importance of human capital and relational capital for innovation in knowledge-intensive firms (Capiello et al., 2020). Regarding accommodation and food services, results from the present study evidenced that these firms needs to focus on the development of human capital (the IC dimension with the lowest mean), in line with previous studies that highlighted the relevance of human capital with information technology (Rudež \& Mihalič, 2007) and structural capital (Kim et al., 2012).

In manufacturing companies, there is a greater predominance of structural capital. Surprisingly, the present study showed a predominance of human capital in firms from the construction sector. Even though Lin et al. (2018) posit that business performance in the construction industry relies highly on IC, a recent study by Duodu \& Rowlinson (2019) with firms from the construction sector in Hong Kong evidenced that both the structural and relational dimensions have a positive influence on innovation performance, while the effect of human capital on innovation is through the other dimensions. It may be proposed that firms from the construction sector in Loja may be able to increase their innovation performance if they focus on improving their structural and relational capital.

In this regard, it is important to note that Machado, et al. (2017) highlighted the differences in the IC configurations that companies of various types have, and in turn, stated that there is always a synergy between the components of the IC, which act together to achieve competitiveness.

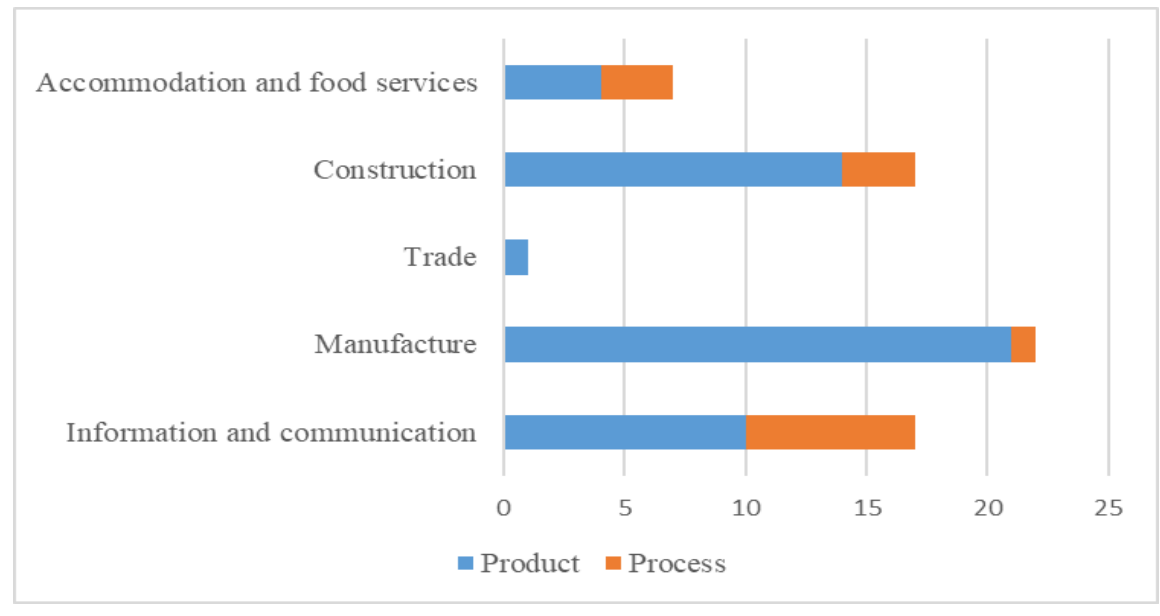

Fig 4. Predominant type of innovation by economic sector Source: Results of the study.

Due to the characteristics of the sample and the context of the study, there is more product innovation (in goods and services) in the economic sectors analyzed represented in Chart 4. Recent research has shown that companies in Latin America tend to develop incremental product innovations, as they are constantly looking for foreign product designs and adapting them to local environments (Davila, et al. 2018). In line with Hipp \& Grupp (2005), in non-knowledge-intensive services (e.g. ICT, construction, housing, and food services) where cost and time 


\section{ENTREPRENEURSHIP AND SUSTAINABILITY ISSUES}

ISSN 2345-0282 (online) http://jssidoi.org/jesi/

2020 Volume 8 Number 2 (December)

http://doi.org/10.9770/jesi.2020.8.2(61)

Make your research more visible, join the Twitter account of ENTREPRENEURSHIP AND SUSTAINABILITY ISSUES: @Entrepr69728810

efficiency are important, the present study found that innovation has been carried out on products. Studies by Kianto et, al. (2010), Schilling (2011), and Buenechea-Elberdin (2017) also state that the intensity with which the IC influences innovative performance will also depend on the location of the company, the industry to which it belongs, its level of technology, and its size.

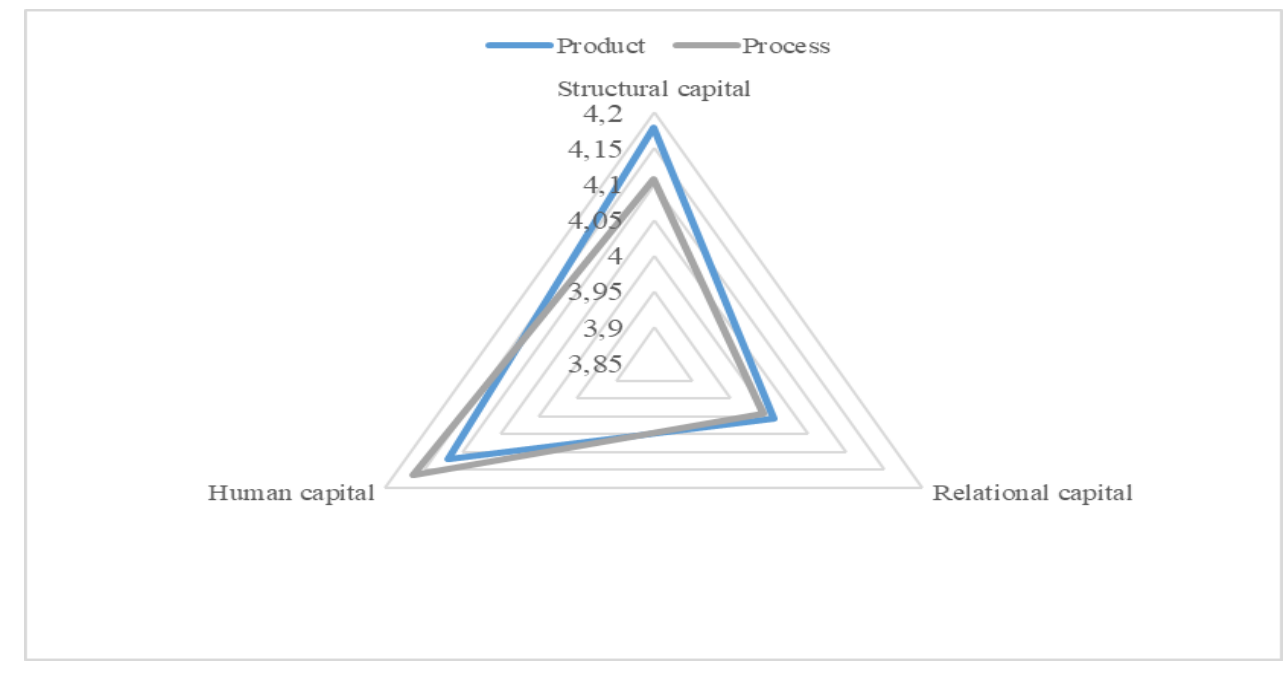

Fig 5. IC dimension averages by type of innovation Source: Results of the study.

Figure 5 shows that companies which innovate in processes have different IC structures to companies that innovate in goods or services. The first ones have a greater focus on their human capital, because the knowledge, experience, skills, and creativity of the employees are fundamental for the creation of new processes (Mariz Perez et al. 2012). Companies that innovate in products also develop a higher structural capital, as this type of innovation is more complex (mainly in emerging countries), because it requires an adequate integration of specialized knowledge in people, towards final goods and services, supported by organizational processes and technology (Davila, et al. 2018). The support of organizational processes and technology in the launching of products contributes to the reduction of production costs, the faster completion of development projects, to the creation of spaces for innovation, to improving decision-making and results coordination, and to increasing the sales or revenue from new products and services (Huang, et al. 2010; Chen, et al.,2017).

At the same time, the present study showed that all companies, regardless of the type of innovation they present, pay attention to relational capital as external knowledge is a critical input for the innovative performance of organizations (Fosfuri \& Tribó, 2008). On this point, Subramaniam \& Youndt (2005) state that organizations generate innovations when their individual experts communicate, network, and share knowledge with each other. Dost, et al. (2016) concluded that IC is significantly associated with innovation, whether in products or processes, which is consistent with the results of the present research. 


\section{ENTREPRENEURSHIP AND SUSTAINABILITY ISSUES}

ISSN 2345-0282 (online) http://jssidoi.org/jesi/

2020 Volume 8 Number 2 (December)

http://doi.org/10.9770/jesi.2020.8.2(61)

Make your research more visible, join the Twitter account of ENTREPRENEURSHIP AND SUSTAINABILITY ISSUES: @Entrepr69728810

\section{Conclusions}

The main academic contribution of this study was the adaptation and verification of a scale to analyze IC in emerging countries. This scale can be used in future research, which seeks to identify relationships between IC and organizational outcomes, such as innovation and financial performance, in companies located in Ecuador or other emerging countries.

In addition, the main empirical contribution of this study is the description of the components of IC in Ecuadorian companies. The results show that the configurations of IC may vary in companies according to their sector and the type of innovation usually practiced by each company. This study identified some opportunities related to IC, for improving their innovation performance in firms from Loja. Accommodation and food services may focus on the development of human capital, and construction firms may improve their innovativeness if they increase their efforts to enhance both structural and relational capital. A dynamic view of IC covers the integration of all its components, which means considering the effects and relationships with each other, in order to understand in a broad and organized way the strengths of each organization, and to promote successful innovation.

IC appears to be an important potential engine of innovation for Ecuadorian companies, especially those located in the city of Loja. However, a proposition of this study is that not all companies need a high level of development of all IC dimensions. The level of development required for each dimension depends on its own characteristics, such as economic sector, size, or location. However, it is important to emphasize that all IC dimensions should work together to ensure that the IC contributes to creating value (Casas Novas et al. 2017). Further studies may help to explain which levels of IC and its dimensions are needed in order to achieve superior innovation performance, taking into consideration their sector and size. This will allow the development of guidelines for decision makers improving the efficiency in the allocation of its resources, by prioritizing the dimensions of IC that are most relevant to each organization.

\section{References}

Allameh, S. (2018). Antecedents and consequences of intellectual capital. Journal of Intellectual Capital, 19(5): 858-874. https://doi.org/10.1108/JIC-05-2017-0068.

Agostini, L., Nosella, A., \& Filippini, R. (2017). Does intellectual capital allow improving innovation performance? A quantitative analysis in the SME context. Journal of Intellectual Capital, 18(2): 400-418. https://doi.org/10.1108/JIC-05-2016-0056

Babin, B. \& Boles, J. (1996). The effects of perceived co-worker involvement and supervisor support on service provider role stress, performance and job satisfaction. Journal of Retailing, 2: 57-75. https://doi.org/10.1016/S0022-4359(96)90005-6

Baregheh, A, J Rowley \& S Sambrook (2009). Towards a multidisciplinary definition of innovation. Management Decision, 47: 13231339. https://doi.org/10.1108/00251740910984578

Bayraktaroglu, A. E., Calisir, F., \& Baskak, M. (2019). Intellectual capital and firm performance: An extended VAIC model. Journal of Intellectual Capital., 20(3): 406-425. https://doi.org/10.1108/JIC-12-2017-0184

Berezinets, I., Garanina, T. \& Ilina, Y. (2016). Intellectual capital of a board of directors and its elements: introduction to the concepts. Journal of Intellectual Capital, 17(4): 632-653. https://doi.org/10.1108/JIC-01-2016-0003 


\section{ENTREPRENEURSHIP AND SUSTAINABILITY ISSUES}

ISSN 2345-0282 (online) http://jssidoi.org/jesi/

2020 Volume 8 Number 2 (December)

http://doi.org/10.9770/jesi.2020.8.2(61)

Make your research more visible, join the Twitter account of ENTREPRENEURSHIP AND SUSTAINABILITY ISSUES: @Entrepr69728810

Berraies, S. (2019). The effect of enterprise social networks use on exploitative and exploratory innovations: Mediating effect of subdimensions of intellectual capital. Journal of Intellectual Capital, 20, 3:426-452. https://doi.org/10.1108/JIC-02-2019-0030

Berry, L., Conant, J. \& Parasuraman, A. (1991). A Framework for Conducting a Service Marketing Audit. Journal of the Academy of Marketing Science, 19: 255-268. https://doi.org/10.1007/BF02726500

Bontis, N. (1998). Intellectual capital: an exploratory study that develops measures and models. Management Decision, 36(2): 63-76.

Bontis, N., Chua, W. \& Richardson, S. (2000). Intellectual capital and the nature of business in Malaysia. Journal of Intellectual Capital, 1 (1): 85-100.

Bontis, N. (2001). Assessing knowledge assets: a review of the models used to measure intellectual capital. International Journal of Management Reviews, (1): 41-60.

Bontis, N., Janoševic, S. \& Dženopoljac, V. (2015). Intellectual capital in Serbia's hotel industry. International Journal of Contemporary Hospitality Management, 2(6): 1365-1384. https://doi.org/10.1108/IJCHM-12-2013-0541

Bontis, N., \& Fitz-Enz, J. (2002). Intellectual capital ROI: a causal map of human capital antecedents and consequents. Journal of Intellectual Capital, 3(3): 223-247. https://doi.org/10.1108/14691930210435589

Bozbura, F. T. (2004). Measurement and application of intellectual capital in Turkey. The Learning Organization, 11(4/5): 357-367. https://www.learntechlib.org/p/75559/.

Buenechea-Elberdin, M. (2017). Structured literature review about intellectual capital and innovation. Journal of Intellectual Capital, 18 (2): 262-285. https://doi.org/10.1108/JIC-07-2016-0069

Buenechea-Elberdin, M., Sáenz, J., \& Kianto, A. (2018). Knowledge management strategies, intellectual capital, and innovation performance: a comparison between high-and low-tech firms. Journal of Knowledge Management, 22(88): 1757-1781. https://doi.org/10.1108/JKM-04-2017-0150

Bueno, E., Salmador, M. \& Rodriguez, O. (2004). The Role of Social Capital in Today's Economy: Empirical Evidence and Proposal of a New Model of Intellectual Capital. Journal of Intellectual Capital, 5: 556-574. https://doi.org/10.1108/14691930410567013

Cabello-Medina, C., López-Cabrales, Á., \& Valle-Cabrera, R. (2011). Leveraging the innovative performance of human capital through HRM and social capital in Spanish firms. International Journal of Human Resource Management, 22(04): 807-828.

Cabrilo, S., \& Dahms, S. (2018). How strategic knowledge management drives intellectual capital to superior innovation and market performance. Journal of Knowledge Management, 22(3): 621-648. https://doi.org/10.1108/JKM-07-2017-0309

Cabrita, M. D. R., \& Bontis, N. (2008). Intellectual capital and business performance in the Portuguese banking industry. International Journal of Technology Management, 43(1-3). 212-237.

Capello, R., \& Faggian, A. (2005). Collective learning and relational capital in local innovation processes. Regional studies, 39(1): 75-87. https://doi.org/10.1080/0034340052000320851

Calantone, R.J., Cavusgil, S.T. \& Zhao, Y. (2002). Learning orientation, firm innovation capability and firm performance. Industrial Marketing Management, 31: 515-24. https://doi.org/10.1016/S0019-8501(01)00203-6

Cappiello, G., Giordani, F., \& Visentin, M. (2020). Social capital and its effect on networked firm innovation and competitiveness. Industrial Marketing Management. https://doi.org/10.1016/j.indmarman.2020.03.007

Carmeli, A. \& Tishler, A. (2004). The relationships between intangible organizational elements and organizational performance. Strategic Management Journal, 25: 1257-1278. https://doi.org/10.1002/smj.428

Casas Novas, J. María do Céu. G., \& Sousa, A. (2017). The role of management accounting systems in the development of intellectual capital. Journal of Intellectual Capital, 18(2): 286-315. https://doi.org/10.1108/JIC-08-2016-0079 


\section{ENTREPRENEURSHIP AND SUSTAINABILITY ISSUES}

ISSN 2345-0282 (online) http://jssidoi.org/jesi/

2020 Volume 8 Number 2 (December)

http://doi.org/10.9770/jesi.2020.8.2(61)

Make your research more visible, join the Twitter account of ENTREPRENEURSHIP AND SUSTAINABILITY ISSUES: @Entrepr69728810

Chahal, H. \& Bakshi, P. (2015). Examining intellectual capital and competitive advantage relationship: role of innovation and organizational learning. International Journal of Bank Marketing, 33 (3): 376-399. https://doi.org/10.1108/IJBM-07-2013-0069

Chen, J.; Zhu, Z. y Yuan, H. (2004). Measuring intellectual capital: a new model and empirical study, Journal of Intellectual Capital, 5:195-212. https://doi.org/10.1108/14691930410513003

Chen, X., Zhou, Y., Probert, D. \& Su, J. (2017). Managing knowledge sharing in distributed innovation from the perspective of developers: empirical study of open source software projects in China. Technology Analysis \& Strategic Management, 29(1): 1-22.

Creswell, J. W., \& Creswell, J. D. (2017). Research design: Qualitative, quantitative, and mixed methods approaches. Sage publications

Curado, C. (2008). Perceptions of knowledge management and intellectual capital in the banking industry. Journal of Knowledge Management, 12(3): 141 - 155. https://doi.org/10.1108/13673270810875921

Davey, J., Schneider, L.\& Davey, H. (2009). Intellectual capital disclosure and the fashion industry. Journal of Intellectual Capital, 10(3): 401-424. https://doi.org/10.1108/14691930910977815

Dávila, G. A., Durst, S., \& Varvakis, G. (2018). Knowledge absorptive capacity, innovation, and firm's performance: insights from the South of Brazil. International Journal of Innovation Management, 22(02)

Dávila, G. A., Andreeva, T., \& Varvakis, G. (2019). Knowledge Management in Brazil: What Governance Mechanisms Are Needed to Boost Innovation. Management and Organization Review, 1(30): 857-886. https://doi:10.1017/mor.2019.10

Dorrego, P. F., Costa, R. V., \& Fernández, C. F. J. (2013). Product innovation and relational capital: Evidence from Portugal. Electronic Journal of Knowledge Management, 11(4): 295.

Dost, M., Badir, Y.F., Ali, Z. \& Tariq, A. (2016). The impact of intellectual capital on innovation generation and adoption. Journal of Intellectual Capital, 4: 675-695. https://doi.org/10.1108/JIC-04-2016-0047

Dumay, J.C. \& Garanina, T. (2013). Intellectual capital research: a critical examination of the third stage. Journal of Intellectual Capital, 1(1): 10-25. https://doi.org/10.1108/14691931311288995

Dumay, J. (2016). A critical reflection on the future of intellectual capital: from reporting to disclosure. Journal of Intellectual Capital, 17(1): 168-184. https://doi.org/10.1108/JIC-08-2015-0072

Duodu, B. \& Rowlinson, S. (2019). Intellectual capital for exploratory and exploitative innovation: Exploring linear and quadratic effects in construction contractor firms, Journal of Intellectual Capital, 20(3): 382-405. https://doi.org/10.1108/JIC-08-2018-0144

Dženopoljac, V., Janošević, S. \& Bontis, N. (2016). Intellectual capital and financial performance in the Serbian ICT industry. Journal of Intellectual Capital, 17(2): 373-396. https://doi.org/10.1108/JIC-07-2015-0068

Edvinsson, L. \& Sullivan, P. (1996). Developing a model for managing intellectual capital. European Management Journal, 14(4): 356364 .

Edvinsson, L. \& Malone, M. (1997). Intellectual Capital: The Proven Way to Establish YourCompany's Real Value by Measuring its Hidden Brainpower. King's Lynn and London: Biddles Ltda.

Edvinsson, L. \& Malone, M. (1997). Intellectual Capital: Realizing Your Company's True Value by Finding its Hidden Brainpower. New York: Harper Collins Publishers.

Engelman, R. M., Fracasso, E. M., Schmidt, S., \& Zen, A. C. (2017). Intellectual capital, absorptive capacity and product innovation. Management Decision, 55(3): 474:490. https://doi.org/10.1108/MD-05-2016-0315

Fernández, E., Montes, JM \& Vázquez, CJ (2000). Typology and strategic analysis of intangible resources: a resource-based approach. Technovation, 20(2): 81-92. http://citeseerx.ist.psu.edu/viewdoc/download?doi=10.1.1.464.2528\&rep=rep1\&type=pdf 


\section{ENTREPRENEURSHIP AND SUSTAINABILITY ISSUES}

ISSN 2345-0282 (online) http://jssidoi.org/jesi/

2020 Volume 8 Number 2 (December)

http://doi.org/10.9770/jesi.2020.8.2(61)

Make your research more visible, join the Twitter account of ENTREPRENEURSHIP AND SUSTAINABILITY ISSUES: @Entrepr69728810

FitzPatrick, M., Davey, J., Muller, L. \& Davey, H. (2013). Value-creating assets in tourism management: applying marketing's servicedominant logic in the hotel industry. Tourism Management, 36: 86-98. https://doi.org/10.1016/j.tourman.2012.11.009

Fornell, C., \& Larcker, D. F. (1981). Evaluating structural equation models with unobservable variables and measurement error. Journal of Marketing Research, 18(1): 3950.

Fosfuri, A., \& Tribó, J. A. (2008). Exploring the antecedents of potential absorptive capacity and its impact on innovation performance. Omega, 36(2): 173-187. https://doi.org/10.1016/j.omega.2006.06.012

Gallego, I. y Rodríguez, L. (2005). Situation of Intangibles Assets in Spanish Firms: An Empirical Analysis. Journal of Intellectual Capital, 6: 105-126. https://doi.org/10.1108/14691930510574690

Ganesan, Shankar \&Weitz. (1996). The Impact of Staffing Policies on Retail Buyer Job Attitudes and Behaviors. Journal of Retailing, 72 (1): 31-56. https://doi.org/10.1016/S0022-4359(96)90004-4

Global Innovation Index (GII, 2019), Report GII. https://www.globalinnovationindex.org/gii-2019-report

Goebel, V. (2015). Estimating a measure of intellectual capital value to test its determinants. Journal of Intellectual Capital, 16(1): 101120. https://doi.org/10.1108/JIC-12-2013-0118

Goyzueta, S. (2013). Management model for family businesses with growth and sustainability perspectives. Perspectives Cochabamba: Bolivian Catholic University, 16(31): 87-132.

Granelli, A., \& Robotti, O. (2016). Introduction. The rewarding value of diversity. The key to making your company stronger, more creative and competitive. Milan: Harvard Business Review Italy: 7-14

Hair, J. F., Black, W. C., Babin, B. J., Anderson, R. E., \& Tatham, R. L. (2006). Multivariate data analysis. Uppersaddle River. NJ: Pearson Prentice Hall.

Hartline, M. \& Farrell, O.C. (1996). The Management of Customer-Contact Service Employees: An empirical Investigation. Journal of Marketing, 60: 52-70. https://doi.org/10.2307 / 1251901

Huang, T.T., Chen, L. \& Stewart, R.A. (2010). The moderating effect of knowledge sharing on the relationship between manufacturing activities and business performance. Knowledge Management Research \& Practice, 8(4): 285-306. http://www.palgravejournals.com/kmrp/journal/v8/n4/abs/kmrp201021a.html

Hipp, C., \& Grupp, H. (2005). Innovation in the service sector: The demand for service-specific innovation measurement concepts and typologies. Research policy, 34(4): 517-535. https://doi.org/10.1016/j.respol.2005.03.002

INEC (2011). Economic census results. Ecuador: Presentation of Loja. Recovered from: https://www.ecuadorencifras.gob.ec.

Inkinen, I. (2015). Review of empirical research on intellectual capital and firm performance. Journal of Intellectual Capital, 16(3): 518 565. https://doi.org/10.1108/JIC-01-2015-0002

IRSE (2007). Indice de Responsabilidad Social - ACDE - DERES, ACDE, Montevideo.

Jardon, C. M., \& Susana Martos, M. (2012). Intellectual capital as competitive advantage in emerging clusters in Latin America. Journal of Intellectual Capital, 13(4): 462-481. https://doi.org/10.1108/14691931211276098.

Jordão, R. \& Novas, J. (2017). Knowledge management and intellectual capital in networks of small and medium-sized enterprises. Journal of Intellectual Capital, 18(3): 667-692. https://doi.org/10.1108/JIC-11-2016-0120

Keong Choong, K. (2008). Intellectual capital: definitions, categorization and reporting models. Journal of Intellectual Capital, 9(4): 609638. https://doi.org/10.1108/14691930810913186

Kianto, A., Hurmelinna-Laukkanen, P. \& Ritala, P. (2010). Intellectual capital in service-and product-oriented companies. Journal of Intellectual Capital, 11(3): 305-325. https://doi.org/10.1108/14691931011064563 


\section{ENTREPRENEURSHIP AND SUSTAINABILITY ISSUES}

ISSN 2345-0282 (online) http://jssidoi.org/jesi/

2020 Volume 8 Number 2 (December)

http://doi.org/10.9770/jesi.2020.8.2(61)

Make your research more visible, join the Twitter account of ENTREPRENEURSHIP AND SUSTAINABILITY ISSUES: @Entrepr69728810

Kianto, A., Sáenz, J., \& Aramburu, N. (2017). Knowledge-based human resource management practices, intellectual capital and innovation. Journal of Business Research, 81: 11-20. https://doi.org/10.1016/j.jbusres.2017.07.018

Kim, T., Kim, W. G., Park, S. S. S., Lee, G., \& Jee, B. (2012). Intellectual Capital and Business Performance: What Structural Relationships Do They Have in Upper-Upscale Hotels?. International Journal of Tourism Research, 14(4): 391-408. https://doi.org/10.1002/jtr.1868

Kujansivu, P. \& Lönnqvist, A. (2007). Investigating the value and efficiency of intellectual capital. Journal of Intellectual Capital, 8(2): 272-287. https://doi.org/10.1108/14691930710742844

Lev, B. (2001). Intangibles: Management, Measurement, and Reporting, Washington, DC: Brookings Institution Press.

Lin, D. J., Yu, W. D., Wu, C. M., \& Cheng, T. M. (2018). Correlation between intellectual capital and business performance of construction industry-an empirical study in Taiwan. International Journal of Construction Management, 18(3): 232-246. https://doi.org/10.1080/15623599.2017.1315528

López, E. (2013). Women in companies, professions and non-traditional occupations: The experience of Puerto Rico. Global Conference on Business and Finance Proceedings, 8(2): 1564-1574.

McGregor, J., Tweed, D. \& Pech, R. (2004). Human capital in the new economy: devil's bargain. Journal of Intellectual Capital, 5(1): 153164. https://doi.org/10.1108/14691930410512978

Machado R., Fracasso, E., Schmidt, S. \& Carneiro, A. (2017). Intellectual capital, absorption capacity and product innovation. Management Decision, 55(3): 474-490. https://doi.org/10.1108 / MD-05-2016-0315

Mariz-Perez, RM, Teijeiro-Alvarez, MM \& Garcia-Alvarez, MT (2012). The relevance of human capital as an engine of innovation. Cuadernos de Economía, 35(98): 68-76.

Marqués, D. P., Simón, F. J. G., \& Carañana, C. D. (2006). The effect of innovation on intellectual capital: an empirical evaluation in the biotechnology and telecommunications industries. International Journal of Innovation Management, 10(01): 89-112. https://pdfs.semanticscholar.org/4dcd/3a5bcacfc44ef200834c01c647503c56086a.pdf

Marr, B., Schiuma, G. \& Neely, A. (2004). Intellectual capital-defining key performance indicators for organizational knowledge assets. Business Process Management Journal, 10(5): 551-569. https://doi.org/10.1108/14637150410559225

Martín-de-Castro, G., Delgado-Verde, M., López-Sáez, P. \& Navas-López, J.E. (2011). Towards an intellectual capital-based view of the firm: origins and nature. Journal of Business Ethics, 98(4): 649-662. https://doi.org/10.1007/s10551-010-0644-5

Martinez-Torres, M. (2006). A procedure to design a structural and measurement model of intellectual capital: an exploratory study. Information \& Management, 43(5): 617-626. https://doi.org/10.1016/j.im.2006.03.002

Matricano, D. (2016). The impact of intellectual capital on start-up expectations. Journal of Intellectual Capital, 17(4): 654-674. https://doi.org/10.1108/JIC-04-2016-0040

Maurer, I., Bartsch, V., \& Ebers, M. (2011). The value of intra-organizational social capital: How it fosters knowledge transfer, innovation performance, and growth. Organization Studies, 32(2): 157-185. https://doi.org/10.1177/0170840610394301

Nunnally, J. C., \& Bernstein, I. H. (1994). Psychological theory. New York, NY: MacGraw-Hill: 131147.

Nazari, J.A. \& Herremans, I.M. (2007). Extended VAIC model: measuring intellectual capital components. Journal of Intellectual Capital, 8(4): 595-609. https://doi.org/10.1108/14691930710830774

Peña, I. (2002). Intellectual capital and business start-up success. Journal of Intellectual Capital, 3(2): 180-198. https://doi.org/10.1108/ $\underline{14691930210424761}$ 


\section{ENTREPRENEURSHIP AND SUSTAINABILITY ISSUES}

ISSN 2345-0282 (online) http://jssidoi.org/jesi/

2020 Volume 8 Number 2 (December)

http://doi.org/10.9770/jesi.2020.8.2(61)

Make your research more visible, join the Twitter account of ENTREPRENEURSHIP AND SUSTAINABILITY ISSUES: @Entrepr69728810

Petty, R. \& Cuganesan, S. (2005). Voluntary disclosure of intellectual capital by Hong Kong companies: examining the size, industry and growth effects over time. Australian Accounting Review, 15(2): 40 -7. https://doi.org/10.1111 / j.1835-2561. 2005.tb00291.x

Roberts, H. (2003). Management accounting and the knowledge production process in Bhimani, Management Accounting in the Digital Economy, Oxford University Press: 260-283

Rodríguez-Suárez, P., Pico-González, B., \& Méndez-Ramírez, F. (2013). Innovative capacity in the family business as an area of opportunity towards the development of Mexico. Economy, Society and Territory, 13(43): 779-794. http://www.scielo.org.mx/pdf/est/v13n43/v13n43a9.pdf

Roos, J., Roos, G., Dragonetti, N. \& Edvinsson, L. (1997). Intellectual Capital: Navigating the New Business Landscape, London: Macmillan Press Ltda. https://www.palgrave.com/gp/book/9780333694794

Roos, G. (2017). Knowledge management, intellectual capital, structural holes, economic complexity and national prosperity. Journal of Intellectual Capital, 18(4): 745-770. https://doi.org/10.1108/JIC-07-2016-0072

Rudež, H. N., \& Mihalič, T. (2007). Intellectual capital in the hotel industry: A case study from Slovenia. International Journal of Hospitality Management, 26(1): 188-199. https://doi.org/10.1016/j.ijhm.2005.11.002

Sayyed A. (2018) Antecedents and consequences of intellectual capital: The role of social capital, knowledge sharing and innovation. Journal of Intellectual Capital, 19(5): 858-874. https://doi.org/10.1108/JIC-05-2017-0068

Schilling, M. (2011). Strategic management of technological innovation. Nueva York: McGraw Hill,

Schumpeter, J. (1927). The explanation of the business cycle. Economica, 21: 286-311.

Seleim, A., Ashour, A. \& Bontis, N. (2004). Intellectual capital in Egyptian software firms. The Learning Organization, 11: 332-346. https://doi.org/10.1108/09696470410538233

Sharabati, A., Jawad, S. \& Bontis, N. (2010). Intellectual capital and business performance in the pharmaceutical sector of Jordan. Management Decision, 48(1): 105-131. https://doi.org/10.1108/00251741011014481

Song, M. \& Parry, M. (1993). R\&D Marketing Integration in Japanese High-Technology Firms: Hypothesis and Empirical Evidence, Journal of the Academy of Marketing Science, 21:125-133. https://doi.org/10.1007/BF02894423

Starovic, D. \& Marr, B. (2004). Understanding Corporate Value: Managing and Reporting Intellectual Capital. London: The Chartered Institute of Management Accountants (CIMA) and Cranfield University.

Stewart, T.A. \& Losee, S. (1994). Your company’s most valuable asset: intellectual capital. Fortune, 130(3): 68-73.

Stewart, T.A (1997). Intellectual Capital: The New Wealth of Organizations, Currency and Doubleday, New York: London.

Subramaniam, M. \& Youndt, M.A. (2005). The influence of intellectual capital on the types of innovative capabilities. Academy of Management Journal, 48(3): 450-464. https://doi.org/10.5465/amj.2005.17407911

Sullivan, P. H. (1998). Profiting from intellectual capital: Extracting value from innovation. John Wiley \& Sons.

Sullivan, P.H. (2000), Value-Driven Intellectual Capital: How to Convert Intangible Corporate Assets into Market Value. New York: Wiley. https://doi.org/10.1108/14691930010359234

Superintendencia de Compañías Valores y Seguros. (2020). Statistics https://www.supercias.gob.ec/portalscvs/

Teece, DJ (2010). Business models, business strategy and innovation. Long Range Planning, 43: 172-194. https://doi.org/10.1016/j.lrp.2009.07.003

Tippins, M. \& Sohi, R. (2003). It competency and firm performance: Is organizational learning a missing link?. Strategic Management Journal, 24: 745-761. 


\section{ENTREPRENEURSHIP AND SUSTAINABILITY ISSUES}

ISSN 2345-0282 (online) http://jssidoi.org/jesi/

2020 Volume 8 Number 2 (December)

http://doi.org/10.9770/jesi.2020.8.2(61)

Make your research more visible, join the Twitter account of ENTREPRENEURSHIP AND SUSTAINABILITY ISSUES: @Entrepr69728810

Tootifar Tehranpoor, M. \& Ziya, B. (2014). The effect of intellectual capital to small Sport businesses innovative in Tehran. Entrepreneurship Development, 7(2): 254-269. https://doi.org/10.1002 / smj.337

Trequattrini, R., Nappo F., Lardo A. \& Cuozzo B. (2018). Intellectual Capital and Gender Capital: The Case of Italian Universities. In: Paoloni P., Lombardi R. (eds) Gender Issues in Business and Economics. Springer Proceedings in Business and Economics. Springer, Cham

Ulrich, D., Zenger, J. \& Smallwood, N. (1999). Results Based Leadership. Boston. Harvard Business School Press,

Verbano, C. \& Crema, M. (2016). Linking technology innovation strategy, intellectual capital and technology innovation performance in manufacturing SMEs. Technology Analysis \& Strategic Management, 28(5): 524-540. https://doi.org/10.1080/09537325.2015.1117066

Warn, J. (2005). Intangibles in commercialisation: The case of Air Navigation Services in the South Pacific. Journal of Intellectual Capital, 6(1): 72-88. https://doi.org/10.1108/14691930510574672

Wee, J.C. \& Chua, A.Y. (2016). The communication of intellectual capital: the 'whys' and 'whats'. Journal of Intellectual Capital, 17 (3): 414-438. https://doi.org/10.1108/JIC-01-2016-0007

Weerawardena, J. (2003). The role of marketing capability in innovation-based competitive strategy. Journal of strategic marketing, 11(1): 15-35. https://doi.org/10.1080/0965254032000096766

World Bank (2020). Data. https://datos.bancomundial.org/indicator/NY.GDP.MKTP.KD.ZG?locations=EC

Yli-Renko, H., Autio, E. \& Sapienza, H. (2001). Social Capital, Knowledge Acquisition, and Knowledge Exploitation in Young Technology-based Firms, Strategic Management Journal, 22: 587-613. https://www.jstor.org/stable/3094322

Youndt, M., Subramanian, M. \& Snell, S. (2004). Intellectual capital profiles: An examination of investments and returns. Journal of Management Studies, 42: 335-361. https://doi.org/10.1111/j.1467-6486.2004.00435.x

Xu, J., \& Li, J. (2019). The impact of intellectual capital on SMEs' performance in China. Journal of Intellectual Capital, 20 (4): 88-509. https://doi.org/10.1108/JIC-04-2018-0074

Zerenler, M., Hasiloglu, S. B., \& Sezgin, M. (2008). Intellectual capital and innovation performance: empirical evidence in the Turkish automotive supplier. Journal of technology management \& innovation, 3(4): 31-40. http://dx.doi.org/10.4067/S0718-27242008000200003

Zhang, H.Y. \& Lv, S. (2015). Intellectual capital and technological innovation: the mediating role of supply chain learning. International. Journal of Innovation Science, 7 (3):199-210. https://doi.org/10.1260/1757-2223.7.3.199

Appendix. Statistical assessment of the instrument to measure IC in companies in Ecuador.

\begin{tabular}{|c|c|c|c|c|c|}
\hline INDICATORS & HC & SC & RC & $\begin{array}{c}\text { Variance } \\
\text { Inflation Factors } \\
\text { (VIF) }\end{array}$ & AUTHORS \\
\hline \multicolumn{6}{|l|}{ HUMAN CAPITAL (HC) } \\
\hline H1. Employee commitment & $\theta .861$ & 0.587 & 0.556 & 4.266 & $\begin{array}{l}\text { Ganesan et al. (1996); Babin \& } \\
\text { Boles (1996) }\end{array}$ \\
\hline H2. Tasks within deadlines & 0.809 & 0.511 & 0.512 & 3.532 & Kianto, A. (2008) \\
\hline H3. Recognition of efforts and improvements & 0.720 & 0.499 & 0.461 & 2.178 & $\begin{array}{l}\text { Mention \& Bontis (2013), } \\
\text { Edvinsson \& Malone (1997) }\end{array}$ \\
\hline
\end{tabular}




\section{ENTREPRENEURSHIP AND SUSTAINABILITY ISSUES}

ISSN 2345-0282 (online) http://jssidoi.org/jesi/

2020 Volume 8 Number 2 (December)

http://doi.org/10.9770/jesi.2020.8.2(61)

Make your research more visible, join the Twitter account of ENTREPRENEURSHIP AND SUSTAINABILITY ISSUES: @Entrepr69728810

\begin{tabular}{|c|c|c|c|c|c|}
\hline H4. Positive attitude to change & 0.761 & 0.539 & 0.597 & 3.080 & $\begin{array}{l}\text { Mention and Bontis (2013), } \\
\text { Edvinsson and Malone (1997) }\end{array}$ \\
\hline H5. Continuing education & 0.770 & 0.566 & 0.535 & 3.418 & Sharabati et al. (2010) \\
\hline H6. Degree of initiative for improvement & 0.785 & 0.518 & 0.566 & 2.720 & Sharabati et al. (2010) \\
\hline H7. Satisfaction towards subordinates & 0.767 & 0.562 & 0.505 & 2.574 & Carmeli (2004) \\
\hline H8. Adaptation to changes- & 0.719 & 0.691 & 0.628 & 2.100 & Hartline \& Ferrell (1996) \\
\hline H9. Competition for the position & 0.734 & 0.723 & $\theta .613$ & 2.267 & $\begin{array}{l}\text { Bontis (1998), Carmeli \& Tishler } \\
\text { (2004) }\end{array}$ \\
\hline H10. Development of creativity & 0.762 & 0.574 & 0.613 & 2.748 & $\begin{array}{l}\text { Bontis (1998), Youndt et al. } \\
\text { (2004) }\end{array}$ \\
\hline H11. Staff rotation & $\theta .351$ & $\theta .177$ & $\theta .158$ & 1.235 & Carmeli \& Tishler (2004) \\
\hline \multicolumn{6}{|l|}{ STRUCTURAL CAPITAL (SC) } \\
\hline E1. Periodic review of the strategic plan & 0.385 & 0.646 & 0.450 & 2.492 & IRSE (2007) \\
\hline E2. Coordination of departments & 0.583 & 0.784 & 0.660 & 2.980 & Berry (1991) \\
\hline E3. Knowledge of activities at all levels- & $\theta .626$ & 0.786 & $\theta .673$ & 2.276 & Ulrich et al. (1999) \\
\hline E4. Incentive to create something new & $\theta .701$ & $\theta .734$ & 0.560 & 2.065 & Song and Parry (1993) \\
\hline E5. Working environment & 0.695 & 0.746 & 0.589 & 2.254 & Kianto (2018) \\
\hline E6. Description of procedures & 0.446 & 0.717 & 0.618 & 2.233 & $\begin{array}{l}\text { Tippins \& Sohi (2003), Youndt, } \\
\text { Subramanian \& Snell (2004) }\end{array}$ \\
\hline E7. Database & 0.495 & 0.759 & 0.581 & 2.677 & IRSE (2007) \\
\hline E8. Information storage and processing & 0.450 & 0.712 & 0.533 & 2.413 & Tippins \& Sohi (2003) \\
\hline E9. Computer systems & 0.392 & 0.606 & 0.433 & 1.885 & Tippins \& Sohi (2003) \\
\hline E10. Use of patents and/or licenses & $\theta .24 \theta$ & $\theta .414$ & $\theta .479$ & 1.434 & $\begin{array}{l}\text { Youndt, Subramanian \& Snell } \\
(2004)\end{array}$ \\
\hline \multicolumn{6}{|l|}{ RELATIONAL CAPITAL (RC) } \\
\hline R1. Customer retainment & 0.604 & 0.670 & 0.796 & 2.565 & $\begin{array}{l}\text { Chen et al. (2004), Gallego \& } \\
\text { Rodríguez (2005) }\end{array}$ \\
\hline R2. Relationship with customers & 0.627 & 0.701 & 0.815 & 2.372 & Yli-Renko et al. (2001) \\
\hline R3. Relationship with suppliers & $\theta .42 \theta$ & $\theta .603$ & 0.680 & 1.978 & $\begin{array}{l}\text { Gallego \& Rodríguez (2005), } \\
\text { Warn (2005) }\end{array}$ \\
\hline R4. Assessment of competiters & 0.327 & 0.544 & 0.595 & 1.609 & $\begin{array}{l}\text { Youndt, Subramanian \& Snell } \\
\text { (2004) }\end{array}$ \\
\hline R5. Cooperation agreements with the sector & $\theta .380$ & 0.326 & 0.571 & 1.448 & $\begin{array}{l}\text { Bontis (1998), Peña (2002), } \\
\text { Bueno et al. (2004) }\end{array}$ \\
\hline $\begin{array}{l}\text { R6. Relationship with universities, institutes or } \\
\text { innovation centers }\end{array}$ & 0.443 & 0.370 & 0.646 & 1.916 & CIC (2003) \\
\hline R7. Knowledge of community needs & 0.490 & 0.463 & 0.685 & 2.100 & IRSE (2007) \\
\hline R8. Socially responsible company & 0.703 & 0.757 & 0.836 & 2.352 & $\begin{array}{l}\text { Carmeli \& Tishler (2004), } \\
\text { Gallego \& Rodríguez (2005) }\end{array}$ \\
\hline
\end{tabular}




\section{ENTREPRENEURSHIP AND SUSTAINABILITY ISSUES}

ISSN 2345-0282 (online) http://jssidoi.org/jesi/

2020 Volume 8 Number 2 (December)

http://doi.org/10.9770/jesi.2020.8.2(61)

Make your research more visible, join the Twitter account of ENTREPRENEURSHIP AND SUSTAINABILITY ISSUES: @Entrepr69728810

Mariuxi PARDO-CUEVA, PhD candidate in Administration - National University of Rosario (Argentina). Master in Integral Audit UTPL. Engineer in "Accounting and Audit" - UTPL. Diploma in Quality Management Audit - UTPL. Diploma in Taxation - UTPL. Work experience: 3 years as an accounting assistant and accountant, also responsible for the purchasing and human resources areas of Ediloja Cía. Ltda. Undergraduate and postgraduate university professor for 11 years in the areas of General Accounting, Audit, Management Accounting, Productive Management, Practicums. Coordinator of the Accounting and Audit degree 2014-2016. Member of the research group Knowledge Management in Organizations (GCO). Teacher: full-time researcher of the Department of Business Sciences, Accounting and Audit Section of the UTPL.

ORCID ID: orcid.org/ 0000-0003-3769-2242

Guillermo Antonio DAVILA, PhD. is Senior Researcher in the Knowledge Engineering Department (www.ngs.ufsc.br) at Federal University of Santa Catarina, UFSC, Florianópolis, Brasil; and Visiting Professor at Universidad Técnica Particular de Loja - UTPL, Ecuador. He has more than 10 years of experience in consultancy, insurance, banking, and public sectors, working in different areas (e.g. FDI attraction, operations management, technology management, technology transfer, KM maturity assessment, innovation management). His research focus is on knowledge management, innovation, and technology transfer between SMEs, KM practices for innovation, and knowledge absorptive capacity. He works as a reviewer for International Journal of Innovation Management, and Brazilian Business Review. His work has been published in Brazilian and international peer-reviewed journals, and he has been awarded at the IFKAD 2017 and 2019 conferences.

ORCID ID: orcid.org/ 0000-0002-1479-2585

Laura Magali CHAMBA-RUEDA, PhD student in Administration at the University of Rosario-Argentina. Master in Business Management, Business Administration Engineer at the Universidad Técnica Particular de Loja - Ecuador. University teacher (undergraduate components: Quality Management, Financial Mathematics, Business Case Analysis, Entrepreneurship and Administration. Postgraduate components: Implementation of a Quality Management System, Implementation of the ISO 26000 standard). Responsible credit experience at Banco Centro Mundo, Financial Assistant at ECOLAC, Research Manager at a call center, Master's Degree Coordinator in Quality Management and Business Management.

ORCID ID: orcid.org/ 0000-0002-4882-0070

Copyright (C) 2020 by author(s) and VsI Entrepreneurship and Sustainability Center

This work is licensed under the Creative Commons Attribution International License (CC BY).

http://creativecommons.org/licenses/by/4.0/

(c) (i) Open Access 